riment $\mathrm{i}$ indledningen til Nordens Mythologi. - Hvis udviklingen i den danske højskole i 1961 gik bort fra kristendommen, går den altså hos Ejvind Larsen tilbage til kristendommen.

\title{
Grundtvigs salmer og hans liv
}

\section{Af William Michelsen}

Eva Meile: „Plant en lilje». Om Grundtvig og 3 af hans salmer. 48 sider, København, Unitas, 1992.

Dette lille studiehefte med omfattende litteraturhenvisninger viser, hvor stor interessen er for sammenhoengen mellem Grundtvigs salmer og hans personlige religiфse udvikling. Det er åbenbart ikke tilstrækkeligt at have de kendte biografiske oplysninger om Grundtvigs liv for at forstå blot de salmer, der står i salmebogen - for ikke at tale om i hans Sang-Værk og hans egne omarbejdelser og senere salmer. Vi trænger til et værk, der gennemgår hele Grundtvigs salmedigtning og hans liv.

\section{Det vingede ord}

\section{Af Hans Hauge}

Peter Balslev-Clausen: Det vingede ord: Om N.F.S. Grundtvigs salmedigtning. (Materialecentralen, København 1991) 143 sider.

Det vingede ord er ikke en oversigt eller gennemgang af Grundtvigs salmedigtning. Der er tale om naerloesning af udvalgte salmer begyndende med »De første salmer «, som første kapitel hedder. Når en bog indeholdende nærlæsning eller analyse af forholdsvis få salmer alligevel kan kaldes en bog om Grundtvigs salmedigtning, så er det, fordi Peter Balslev-Clausen i sin »Indledning « går ud fra noget, der må betegnes som en arbejdshypotese. Den går ud på, at Grundtvig livet igennem »vender tilbage til den samme inspiration og de samme motiver. Takket være denne kontinuitet i forfatterskabet er det muligt at få et indtryk af Grundtvigs grundlæggende tankestruktur (min understregning) (s. 9).« Man kan vel næppe kalde en sådan hypotese overraskende. Den kan se så tilforladelig ud, at man er tilbøjelig til at springe den over. Alligevel vil jeg mene, at Balslev-Clausen ved at fremsætte den, samtidig angiver, at han er ude på at gøre noget nyt eller anderledes i forhold til tidligere analyser af Grundtvigs salmer, som der jo er mange af. Hvad er så det nye, som Balslev-Clausen vil gøre, men som han ikke eksplicit siger, at han vil? Hvad er det, han er ude på 
i sine næranalyser? Jeg vil tillade mig at være så fræk at sige, hvad han vil, og så uhøflig at sige, at han ikke helt er klar over, hvad han vil og faktisk gør. Han laver en strukturel eller endog strukturalistisk analyse af udvalgte salmer. Han ved godt, at han laver en strukturel analyse, for det kalder han sine analyser. Når jeg så alligevel siger, at han ikke synes at være bevidst om, at det er dét, han gør, så er det, fordi han ikke viser nogen bekendthed med strukturalistisk tekstanalyse. En sådan kan kun gøres med basis i en lingvistik. Forstå det ret og ikke som en kritisk bemærkning: Han er en art amatør-strukturalist eller 'barfods-strukturalist'. Han er på en måde nået frem til at kunne lave en sådan læsning på egen hånd. Det er hans store fortjeneste; men det hele ville have været lettere for ham, hvis han havde kendt den fremgangsmåde, som han bruger. $\mathrm{Nu}$ skal han næsten opfinde den selv, selvom den er opfundet og har været praktiseret i mange år. Nævnes skal det dog, at en tidligere Grundtvigfortolker - Helge Toldberg - var en slags para-strukturalist. Retfærdigvis skal det dog tilføjes, at Balslev-Clausen på ingen måde er amatør, når der er tale om viden om Grundtvigs forfatterskab. Det er en bog, man som ikke-ekspert kan lære meget af, og jeg tror såmænd også eksperterne kan lære af dens måde at læse tekster på. Jeg må også tilføje, at det ikke er en let læst - eller tør man sige - 'folkelig' bog? Det er først og fremmest et arbejdsredskab, som kan bruges, hvis man vil gå tæt ind på udvalgte tekster.

Lad mig da vende tilbage til hans tese. Der er kontinuitet i forfatterskabet siger han, og det viser han iøvrigt også i forbindelse med analyserne. Man kan godt kalde det tankevækkende, at han siger og viser det. For Balslev-Clausen er jo, som de fleste, helt på det rene med, at de fleste læsninger af Grundtvig traditionelt understreger springene $\mathrm{i}$ hans opfattelse af både filosofi, poesi og kristendom. Balslev-Clausen nævner endda selv, at Grundtvig går fra at være romantiker til at være lutheraner, hvis man må sige det så enkelt. Det interessante er så, at hvor Grundtvig åbenbart skifter meninger, så forbliver tankestrukturen den samme. Balslev-Clausen registrerer blot, at der er både diskontinuitet og kontinuitet. Hvordan de to forholder sig til hinanden, er der ikke gjort nogen tanker om. Alligevel må ideen være, at tankestrukturen er mere fundamental - „grundlæggende «, som han siger - end holdninger, meninger, teologi, filosofi. Sagen er, at det næppe er så let at forene struktur og historie, som Balslev-Clausen făr det til at se ud. For hvis Grundtvigs meninger ændrede sig, så er den grundlæggende tankestruktur ikke indholdsbestemt. Jeg ville mene, at man bør skelne radikalt mellem digteren Grundtvig og mennesket Grundtvig. Men det kan Balslev-Clausen, sammen med stort set alle andre Grundtvigtolkere (måske med Poul Borum undtaget), ikke. Ikke fordi han ikke vil, men fordi han ikke kan. Han kan ikke, fordi han, samtidig med at han vil lave en strukturel analyse, fastholder, at Grundtvigs salmer er "fuldgyldige udtryk for hans kristne selvforståelse « (min understregning) (s. 7). Han bruger givetvis ordet 'udtryk' uskyldigt. Og hvad betyder, at disse udtryk er 'fuldgyldige'? Hvad er det modsatte? Digte som umiddelbare udtryk for selv og digterens selvforståelse er intet mindre end den romantiske digtopfattelse, der muliggør og legitimerer alle former for biografiske læsninger, dvs. den slags læsninger, som Balslev-Clausen ellers synes at ville undgå. Er der ingen konflikt mellem fuldgyldigt udtryk og så den grundlæggende tankestruktur? 
Hvad siger han nu selv, at den »strukturelle analyse « muliggør? Så vidt jeg kan se, er den kun et prolegomenon. Den skal først »afdække den enkelte salmes indre sammenhæng «. Man skal altså bag om det ydre, der dækker noget indre. Endvidere kan den strukturelle analyse kun afdække de enkelte salmers indre sammenhæng: Hvad med alle salmerne som helhed? Er alle salmerne ikke afhængige af den samme dybdestruktur? Hvis man vil påvise en indre sammenhæng, så er grunden vel, at en Grundtvig-salme i det ydre ikke altid umiddelbart eller fænomenologisk set er sammenhængende. Jeg er faktisk nu heller ikke ganske overbevist om, at de er det. Vi synger jo med glæde "O Kristelighed«, selvom vi ved, at den er et fragment af en større helhed. Desværre, må jeg indskyde, undlader Balslev-Clausen at analysere »De Levendes Land «.

Afdækningen bestemmes ydmygt til kun at være en »forudsætning «. Den skal suppleres med en »teologisk analyse«. Men hvad er det for een? BalslevClausen er her på nippet til at identificere form med struktur, og indholdet er noget, der kommer bagefter, og det skal analyseres teologisk. For en salmes »teologiske indhold hører sammen med og bliver båret frem af dens litterære form«. At 'høre sammen med' og 'blive båret frem af' er ikke det samme. Hvis noget hører sammen, kan det så adskilles? I "Om Religion og Liturgie « er der en pointe om, at filosofi (indhold) og poesi (form) er identiske i Jesu lære. De hører altså sammen, og det går galt, siger Grundtvig, hvis de skilles ad. Jesu lære er hverken kun poesi eller kun filosofi, men identiteten mellem dem. I et lidt andet sprog svarer det til, at mythos og kerygma ikke kan skilles ad, sådan som Bultmann tror, de kan. Kan Balslev-Clausen først analysere strukturelt og så bagefter supplere med en teologisk analyse? Ja, det er vel det, han gør. For han mener vist ikke, når det kommer til stykket, at de faktisk hører sammen. Gør han ikke i sidste instans det, at han opfatter den litterære form - der skal analyseres strukturelt - som et transportmiddel, der 'bærer indholdet frem'. Hvis formen ikke gør andet end at overbringe budskabet, hvorfor er det da vigtigt at vie så megen plads og opfindsomhed på en strukturel analyse af den? Da bliver 'den grundlæggende tankestruktur' noget udvendigt og ligegyldigt. Det bliver først vigtigt at lave de analyser, hvis salmens struktur eller form former det teologiske indhold. Form er ikke en container eller beholder, der lader indholdet upåvirket. Men det synes Balslev-Clausen at mene. Form ændrer indholdet.

De to første kapitler behandler grundigt et tema: Grundtvigs gendigtninger af andres salmer. Der er tale om et par informative kapitler; og Balslev-Clausen går detaljeret til værks. Der er relevante, nærmest filologiske, kommentarer til Grundtvigs ændringer af Kingo, og en fin gennemgang af »Et barn er født i Bethlehem«. Jeg kan ikke her gengive alle bogens enkeltanalyser i detaljer. Men i forbindelse med gendigtningsproblematikken savner jeg virkelig noget. Det er nemlig en helt fantastisk og uhørt historie, at Grundtvig kunne tillade sig at omskrive Kingos salmer. Balslev-Clausen - og stort set alle andre Grundtvigtolkere - tager det blot for givet, at det kan man bare gøre, som om det blot var det samme som at oversætte. Hvad ville han sige til, at Jørgen Gustava Brandt eller Pia Tafdrup begyndte at omskrive og gendigte Grundtvigs salmer? Censurerer Grundtvig ikke Kingo? Var Kingo ikke teologisk korrekt? Eller var det, fordi Grundtvig kunne gøre det bedre? Ændres Kingo teologisk eller poetisk? 
Hvad opnår han ved at gendigte »Et barn er født i Bethlehem«? Igen kommer der en klicheagtig udtalelse om, at han i gendigtningen giver »udtryk for, hvordan han opfattede - og oplevede - julemorgensgudstjenesten « (s. 30). Er den salme blot et udtryk for Grundtvigs oplevelse? Jeg ville ønske, BalslevClausen havde forfulgt et spændende tema, som han kort berører. Grundtvig synes $\mathrm{i}$ dele af sin salmedigtning at være styret af et romantisk motiv om, at man i digtet kan genskabe den tabte barndom. (I „De Levendes Land «, f.eks.) Det er et tema, der styrer f.eks. hele William Wordsworths poesi (og ham kendte Grundtvig jo). Man ville kunne læse »Et barn er født « som en $A$ la recherche du temps perdu. Tænk hvis en sådan recherche var den grundlæggende tankestruktur i Grundtvigs salmedigtning. Den ville da ikke kun være udtryk for det underlige fænomen »dansk kristendom«, i stedet ville man kunne se den salmedigtningen - i forhold til europæisk romantik. Også noget andet er 'karakteristisk' for gendigtningen, siger Balslev-Clausen. „Dens [salmens] indhold bliver til virkelighed, når den synges (p. 30).« Sådan står der. Enten er der her tale om en radikal sproglig idealisme - sproget skaber, hvad det nævner - eller også er det en kliche. For hvad er det for et 'indhold', der bliver virkelighed? Er det barndommen, der kommer tilbage? For lidt senere står der, at det er en "oplevelse «, som han "gengiver «. Altså: Gengiver Grundtvig oplevelser, som han havde haft, i sine salmer, eller gengiver han nogle tankestrukturer? Det kan ikke være helt det samme; for det ville betyde, at oplevelserne også var de samme.

Et kapitel (og kapitlerne er ikke nummererede) hedder »Drøm og virkelighed 1«. Det handler bl.a. om »Velkommen igen«. Atter er den salme en, der "giver udtryk for Grundtvigs oplevelse « (p. 41). Om dette kapitel, og det gælder iøvrigt bogen som helhed, kan man sige, at det viser Balslev-Clausens store inspiration fra Christian Thodberg. Og det er et meget Thodbergsk kapitel. Der er ikke tale om en strukturel analyse, men om en, kunne man kalde det, genetisk. Dvs. om forholdet mellem prædiken og salme; om hvordan salmen blev til. Efter et afsnit om »anmeldelser og salmesyn « (hvor jeg savner flere noter og henvisninger) leveres den første virkeligt grundige strukturelle analyse af »Tag det sorte kort fra graven«. Overskriften er »Gennembrud «. Her ses, at Balslev-Clausen også opererer med andet end kontinuitet, for hvad er et gennembrud andet end diskontinuitet? I denne analyse vrimler det med Balslev-Clausens yndlingsord: Struktur. Der er en »bibelsk struktur « i salmen; der er en »systematisk struktur«. Disse to strukturer, siges det, »står ved siden af hinanden « (p. 55). Jeg tror man kan se, at det lyder noget vagt. Hvad er en systematisk struktur? Hvad vil det sige, at to strukturer 'står ved siden af hinanden'? Det er her jeg mener, at Balslev-Clausen mangler et metasprog; et teknisk sprog til præcist at sige, hvad han mener. Der er flere strukturer i salmen: En verbalstruktur, som »svarer til« en »historisk[e] struktur« (p. 57). I næste kapitel om Sang-Varket analyseres på lignende måde »Hyggelig rolig«. Jeg noterer mig i denne forbindelse, at trods det at vi loves strukturelle analyser, så analyseres intet sted alliteration, rim og rytme. Vil man gå tæt på teksten, så burde den slags med, især da i »Hyggelig rolig«. »Trods længselens smerte« er næste eksempel. I denne forbindelse er det, at vi nok kommer tættest på, hvad der menes med den 'grundlæggende tankestruktur'. Det er noget, der kaldes en »V-struktur «. Jeg har set den omtalt før i Grundtvig-litteraturen, men igen virker den på mig hjemmelavet. Det, man er ude på at beskrive hermed, er såmænd blot et kendt 
fænomen: parallelismer (og dermed kontraster). Balslev-Clausen indfører tilmed noget, der hedder en "vækststruktur« (p. 75). Men hvad den såkaldte "Vstruktur « angår, så er det en struktur vi finder i masser af digte - det er ikke en særlig Grundtvigsk opfindelse. Dermed udsiger man, at hans digte har samme struktur som mange andre digte har. Derfor er hans tankestruktur måske slet ikke 'hans'; men digtets som sådan.

»Rejs op dit hoved « har, siges det, »en ret stram struktur«. Gennemgangen af denne salme består af en lang række identifikationer af de bibelsteder, der er brugt. Det siges her, som flere andre steder, at salmerne er opbygget som prædikener. De må da have 'prædiken-struktur'. Nu står det ikke helt klart, om der menes, de er bygget op som Grundtvigs prædikener eller som en prædiken som sådan. Uanset hvad svaret er, så kunne det være interessant at vide, hvordan en prædiken, sådan i al almindelighed, er bygget op. Hvis de faktisk er det, er de (salmerne) da versificerede prædikener?

Vi får nyttige oplysninger i forbindelse med analysen af »I falmende Blade, du kiølige Vind«. En af de retoriske figurer, Grundtvig oftest benytter, bemærkes eller kommenteres ikke. Jeg tænker på apostrofen (som her i »I falmende Blade « eller $\mathrm{i}$ »O Kristelighed «). »I falmende Blade« benytter ydermere et af de mest yndede romantiske topoi: Altså netop blade, vind som metaforer for inspiration. Tænk på et af de mest berømte apostrofiske digte: Shelleys "Ode to the West Wind «. Grundtvigs digt har V-struktur. Det gennemgås med henblik på at vise det. Her synes jeg dog, at det virker noget mindre overbevisende. Men det må stå hen som en ren påstand. Til slut siges det om V-strukturen, at den i senere salmer brydes op eller forskubbes (p. 126). Hvad mon grunden skulle være?

Balslev-Clausen summerer op i et kapitel, der hedder "Den kirkelige og folkelige sammenhæng «. Igen med en strukturel og til dels tematisk analyse af "Herrens Røst«. Lad det så være indledning til min afslutning. Hvad vil jeg bruge bogen til? Jeg er ikke imponeret af de strukturelle analyser; det må vist være fremgået. Det, jeg kan bruge, er det væld af realkommentarer, der findes. $\mathrm{Og}$ der er $\mathrm{i}$ forbindelse med analyserne adskillige indsigtsfulde tolkninger og læsninger. Jeg vil bruge bogen som håndbog og opslagsbog. Som kommentarbind. Balslev-Clausens styrke er detaljen og det konkrete. Men det generelle er hans svaghed. Det vil jeg vise ved at citere indledningen til sidste kapitel: „Salmerne var Grundtvigs stadige forsøg på at komme til rette med tilværelsen, sådan som han oplevede den: Som den digter, han var, var han i stand til at give sine egne oplevelser den almengyldighed, der gjorde dem til salmer ( $p$. 136). « Sådan noget er højstemt, klichepræget og lyder snarere som afslutningen på et foredrag. Hvad er det for en oplevelseskategori, der hele tiden arbejdes med? At sige 'som den digter, han var' er da ikke en forklaring på, at den private oplevelse bliver almen. Og det er vel næppe heller det almengyldige, der gør salmer til salmer. Det sagde vel ikke engang Grundtvig. Man kunne snarere sige, at 'salmerne var Grundtvigs stadige forsøg på at skrive salmer'. Det var det, han var optaget af. Det store spørgsmål er så, om han ville forny salmesangen. For kategorien 'det nye' er en spændende og uudforsket kategori i Grundtvigs poetik. Dens udforskning kunne bl.a. tage udgangspunkt $i$ indledningsversene til »Ragna-roke« (1817), der indsætter en ganske spændende modsætning mellem geniet og talentet, der endda minder lidt om Kierkegaards mellem 
en apostel og et geni. Modkategorien til 'det nye' eller 'fornyelse' ville være den digteriske genskabelse på et højere niveau af barndommens umiddelbarhed. Endnu et projekt ville være en udforskning af Grundtvig som en digter, der opslugte alle tidligere digte i sig for at tilintetgøre dem og gøre dem til sine. Vi trænger til en ikke-idealistisk tolkning af hans omskrivninger, oversættelser og gendigtninger. Jeg tror ikke, der er tale om en venlig vekselvirkning mellem originalen og så det produkt, Grundtvig leverede, når han var færdig med sin gendigtning.

\title{
Vartovbogen 1991
}

\author{
Af Gustav Albeck
}

Vartovbogen 1991, redigeret af Anna Bojsen-Møller, Jørgen Kristensen og E. Jakob Petersen. Kirkeligt Samfunds Forlag, København 1991.

Traditionen tro frembyder indholdet af Vartovbogen 1991 et bredt og broget spektrum af såvel "verdslige« som religiøst orienterede emner.

Blandt de "verdslige « finder man en så broget buket som Mads Lidegaards skildring af "Grønland under hjemmestyre " og højskoleforstander Hans Henningsens klare og saglige redegørelse for erfaringer og indtryk fra et par rejser i Estland, Letland og Litauen.

Hertil må føjes en mundsmag af et stort og kompliceret emne: „Sprog og følelse«, af Brita Lønstrup.

En anden gruppe artikler henter emner fra kirkelige og bibelske områder. Det gælder Ingrid Kjeldsens "Genfortælling af Biblens beretninger om Moses«, der munder ud $\mathrm{i}$ en tolkning, der synes at tage sigte mod de problemer, som $\mathrm{i}$ vore dage truer den indre fred i Israel. Og det gælder Jens B. Olsens veloplagte, kritiske skildring af Danmarks Radios kirkelige og religiøse udsendelser i de seneste år. Artiklen, der er holdt $\mathrm{i}$ en behagelig knap og koncis, til tider spøgefuld tone, bærer den underfundige titel: „Den elektroniske kristelighed«. Grundtvig figurerer ikke i den. "Det levende ord" er ikke elektronisk.

Derimod møder man den gamle åndskæmpe i tre-fire andre artikler, hvoraf to er "optryk «, sognepræst Jens Ole Henriksens karske 'opsang': "Gud, Grundtvig og det danske folk ( fra "Århus Stift« 1988) og Kirsten Ditlevsens artikel "Grundtvig og jomfru Maria $\mathrm{i}$ en lidt kortere og lettere tilgængelig form end den version, der er trykt i Grundtvig Studier 1991.

Revseren af den »sorte Skole « spores kraftigt i en artikel, skrevet af forstanderen for "Grundtvig Institute « i Nigeria, Kashi L. Ozumba og omhandlende "Grundtvigs rødder i Nigeria «, bevægende vidnesbyrd om vedholdende, næsten håbløse bestræbelser for at udbygge en lille eksisterende "Skole for Livet « i det store afrikanske statsområde Nigeria.

Grundtvig spøger også i Peter Balslev-Clausens stofrige, men måske nok lidt for omstændelige afhandling: "Hvad er det, de synger?« Ikke, som titlen synes 